\section{Detection of Japanese Flounder Antibody against Fimbrial Major Protein of Edwardsiella tarda}

\author{
Takamitsu Sakai ${ }^{*}$, Yasuyuki Miyoshi ${ }^{3}$, \\ Tomomasa Matsuyama ${ }^{2}$, Chihaya Nakayasu', \\ Takashi Kamaishi $^{2}$, Yutaka Fukuda ${ }^{3}$ \\ and Takaji lida ${ }^{2}$ \\ ${ }^{1}$ Tamaki Station, National Research Institute of \\ Aquaculture, Fisheries Research Agency, \\ Mie 519-0423, Japan \\ ${ }^{2}$ National Research Institute of Aquaculture, Fisheries \\ Research Agency, Mie 516-0193, Japan \\ ${ }^{3}$ Fisheries Research Institute, Oita Prefectural Agriculture, \\ Forestry and Fisheries Research Center, \\ Oita 879-2602, Japan
}

(Received October 21, 2010)

\begin{abstract}
A recombinant fimbrial protein of Edwardsiella tarda was designed to detect the specific antibody in Japanese flounder Paralichthys olivaceus. The specific antibody was detected from the fish intraperitoneally injected with $E$. tarda expressing the fimbria on LB agar containing $3 \% \mathrm{NaCl}$, but not from those injected with $E$. tarda without the fimbria, Streptococcus iniae, S. parauberis or viral hemorrhagic septicemia virus. In a flounder farm suffered with edwardsiellosis, the antibody-positive fish increased in ration with the occurrence of mortality. These results suggested that $E$. tarda with the fimbria was important for epidemics of edwardsiellosis at flounder farms.
\end{abstract}

Key words: Edwardsiella tarda, fimbrial protein, immunodot-blot test, Paralichthys olivaceus

Edwardsiella tarda is a facultative anaerobic enterobacterium ${ }^{1)}$ that is known to be the causative agent of edwardsiellosis in freshwater and marine fish ${ }^{2-4)}$. In Japan, the Japanese flounder Paralichthys olivaceus farming industry has suffered particularly serious damage from this disease ${ }^{5)}$. Many studies have investigated the virulence properties of $E$. tarda, in particular, the mechanisms for hemolysis ${ }^{6)}$ and anti-phagocytic killing $^{7,8)}$. As another virulence factor of $E$. tarda, Yasunobu et al. ${ }^{9)}$ reported that hemagglutinating activity and infectivity of $E$. tarda to Japanese flounder are enhanced by the presence of $\mathrm{NaCl}$. In addition,

\footnotetext{
* Corresponding author

E-mail: tasakai@affrc.go.jp
}

hemagglutinating activity was proved to be correlated with the adherence of $E$. tarda to HEp-2 cells ${ }^{10)}$. Fimbria, which contains a $19.3 \mathrm{kDa}$ major subunit, reportedly causes hemagglutination ${ }^{11)}$, and the genes coding fimbria are conserved among fish-pathogenic E. tarda strains ${ }^{12)}$. Therefore, fimbria is considered to be an adhesin essential for $E$. tarda infection in marine fish. To clarify the presence of $E$. tarda having fimbria in Japanese flounder at the farm, this study investigated the production of antibody against fimbria in Japanese flounder by immunodetection with a recombinant protein of fimbrial major subunit.

Template DNA for the recombinant protein was prepared from the E. tarda strain NUF806 by PCR with primers, 5'-GCTAACGGTAAAGTTGAGTTTACG-3' and 5'-TTTATATTCGATGGTGAACGGGC-3', which were designed at nucleotide positions $67-90$ and 509-531, respectively, on the fimbrial major subunit gene etfA of E. tarda (GenBank accession no. AB100170). PCR was performed with Phusion High-Fidelity DNA Polymerase (Finnzymes) according to the manufacturer's protocol. The PCR product was cloned into a His-tagged prokaryotic expression vector pET30 (Novagen) and then transduced into Escherichia coli BL21 (DE3) (Nippon Gene). The recombinant protein was biosynthesized by cultivation using Overnight Express Instant TB Medium (Merck) at $25^{\circ} \mathrm{C}$ for $72 \mathrm{~h}$, then isolated with TALON CellThru Resin (Clontech) according to the manufacturer's protocol and stored in phosphate-buffered saline (PBS) containing 0.02\% sodium azide until use $(100 \mathrm{ng} / \mu \mathrm{L})$. The purified recombinant protein was observed by SDS-PAGE according to Laemmli ${ }^{13)}$ (Fig. 1). This recombinant protein showed the antigenicity against a rabbit antiserum for the fimbrial major subunit protein in the immunoblot-

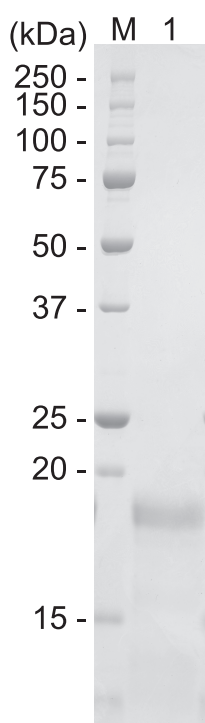

Fig. 1. SDS-PAGE of purified recombinant $E$. tarda fimbrial major subunit. Lane M: molecular weight markers; lane 1: the recombinant protein. 
ting method of Sakai et al. ${ }^{11)}$.

Kim et al. ${ }^{14)}$ reported that ELISA for antibody detection in Japanese flounder has low reproducibility due to non-specific adsorption of the immunoglobulin M (IgM) to blocking reagents on the ELISA plate wells. In the present study, the immuno-dot-blot test was used to detect the antibody because the result was highly reproducible. The recombinant suspension (1 $\mu \mathrm{L}$ ) was transferred onto $0.22-\mu \mathrm{m}$ nitrocellulose membrane (Nitro Bind, GE Osmonics). The membrane was blocked with $3 \%$ non-fat dry milk (Bio-Rad Laboratories) for $1 \mathrm{~h}$ and then immersed in tenfold diluted Japanese flounder serum with PBS containing $0.02 \%$ Tween 20 (T-PBS) for $1 \mathrm{~h}$. After washing 4 times with T-PBS, immunochemical staining was carried out with a mouse monoclonal antibody against the IgM antibody of Japanese flounder ${ }^{15)}$ by use of Immun-Blot Alkaline Phosphatase Assay Kit (Bio-Rad Laboratories) according to the manufacturer's protocol.

Specificity of the recombinant protein in the immuno-dot-blot test was confirmed using sera from Japanese flounder (approximate body weight: $700 \mathrm{~g}$ ) experimentally infected with E. tarda, Streptococcus iniae, S. parauberis or viral hemorrhagic septicemia virus (VHSV), all of which are major pathogens of Japanese flounder ${ }^{16-18)}$. E. tarda NUF806 was cultured on Luria-Bertoni agar (Becton Dickinson, $0.5 \% \mathrm{NaCl}$ agar) without or with added $\mathrm{NaCl}$ at $2.5 \%$ (3\% final concentration; $3 \% \mathrm{NaCl}$ agar) at $27^{\circ} \mathrm{C}$ for $48 \mathrm{~h}$. Production of the fimbrial major subunit protein was observed by the immunoblotting method of Sakai et al. ${ }^{11)}$. S. iniae NUF812 and S. parauberis FPC1060 were cultured on Todd-Hewitt agar (Becton Dickinson) at $27^{\circ} \mathrm{C}$ for $24 \mathrm{~h}$. The VHSV strain JF00Ehi1 was cultured according to the method of Ito et al. ${ }^{19)}$. In each challenge test, fish $(n=30)$ were injected intraperitoneally with $E$. tarda NUF806 at $5.2 \times 10^{4} \mathrm{CFU} /$ fish, S. iniae NUF812 at $8.5 \times 10^{5} \mathrm{CFU} / \mathrm{fish}$, S. parauberis FPC1060 at $1.5 \times 10^{8} \mathrm{CFU} /$ fish and VHSV JFO0Ehi1 at $10^{5.3}$ $\mathrm{TCID}_{50} /$ fish. Fish of the bacterial-challenged or control group were kept at $20 \pm 1^{\circ} \mathrm{C}$ for 30 days in a flowthrough 500-L seawater tank for each group; the VHSVchallenged group was kept in a tank of the same volume at $16 \pm 1^{\circ} \mathrm{C}$. Five fish in the control group was injected with PBS and kept at $16 \pm 1^{\circ} \mathrm{C}$ or $20 \pm 1^{\circ} \mathrm{C}$. Cumulative mortalities of five groups challenged with $E$. tarda NUF806 cells on the $0.5 \%$ and $3 \% \mathrm{NaCl}$ agar, $S$. iniae, $S$. parauberis, VHSV and two control groups at $20^{\circ} \mathrm{C}$ and $16^{\circ} \mathrm{C}$ were 46.7, 50.0,60.0,80.0,60.0, 0 and $0 \%$, respectively. In each group, five fish were randomly-selected from the survival at 30 days after the challenge, and then these sera were pooled and stored at $-80^{\circ} \mathrm{C}$ until used. Production of specific antibody against each pathogen was confirmed by slide agglutination tests with formalin-killed cells of each bacterium or by an indirect fluorescent antibody test against VHSV
JF00Ehi1.

Results of the immuno-dot-blot test of each serum sample are shown in Fig. 2. The antibody reaction against the recombinant protein was detected in sera from fish injected with $E$. tarda grown on the $3 \% \mathrm{NaCl}$ agar but not in the other sera. Yasunobu et al. ${ }^{9)}$ also detected the fimbrial major subunit protein in E. tarda grown in a culture containing $3 \% \mathrm{NaCl}$ but not in cultures containing $<1.5 \% \mathrm{NaCl}$. In this study, the fimbrial major protein was detected in E. tarda NUF806 cultured on the $3 \% \mathrm{NaCl}$ agar by the immunoblotting analysis but not in the cells on the $0.5 \% \mathrm{NaCl}$ agar (Fig. 3). In addition, the fimbrial protein was not observed in the bacterium grown on the $0.5 \% \mathrm{NaCl}$ agar after the cultivation on the $3 \% \mathrm{NaCl}$ agar. Furthermore, the protein was not shown in the bacterium passaged on the $0.5 \% \mathrm{NaCl}$ agar. These results suggested that high concentration of $\mathrm{NaCl}$ was one of induction factors for generation of fimbriae in $E$. tarda and that the expressed fimbrial protein was recognized as an antigen by the immune system of Japanese flounder. In the challenge test with E. tarda cultivated on the $3 \%$ $\mathrm{NaCl}$ agar, the living bacterium was isolated from all sampled flounder having the specific antibody against the fimbrial protein. And the specific antibody was not observed in flounder challenged with $E$. tarda grown on the $0.5 \% \mathrm{NaCl}$ agar. The stability of the expressed fimbrial protein in the fish body is still unknown. The further study is still needed for clarification of the fimbrial function in the virulence of $E$. tarda.

Serum was periodically collected from 10 Japanese flounder randomly sampled at a fish farm in Oita Prefecture, Japan, from August to December 2008.

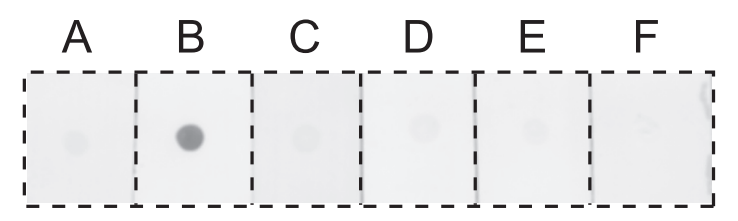

Fig. 2. Antibody reaction of recombinant fimbrial protein in serum from Japanese flounder determined by the immuno-dot-blot test. Serum samples were obtained from fish injected with $E$. tarda grown on $0.5 \% \mathrm{NaCl}$ agar (A); $E$. tarda grown on $3 \% \mathrm{NaCl}$ agar (B); S. iniae (C); S. parauberis (D); VHSV (E); or PBS at $20^{\circ} \mathrm{C}(\mathrm{F})$.

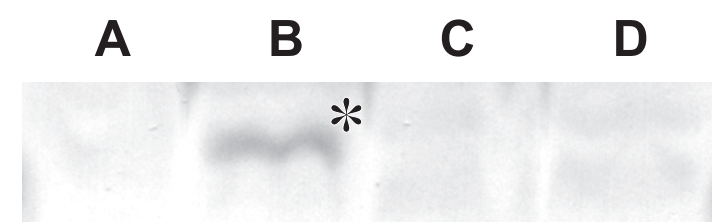

Fig. 3. Immunoblotting analysis of E. tarda NUF806 with a rabbit antiserum against fimbrial protein. The bacterium on the $0.5 \% \mathrm{NaCl}$ agar $(\mathrm{A})$ was cultured on the $3 \% \mathrm{NaCl}$ agar (B). After the cultivation with the $3 \%$ $\mathrm{NaCl}$ agar, the bacterium was passaged twice on the $0.5 \% \mathrm{NaCl}$ agar $(\mathrm{C}$ and $\mathrm{D})$. * Positive reaction against the fimbrial protein. 


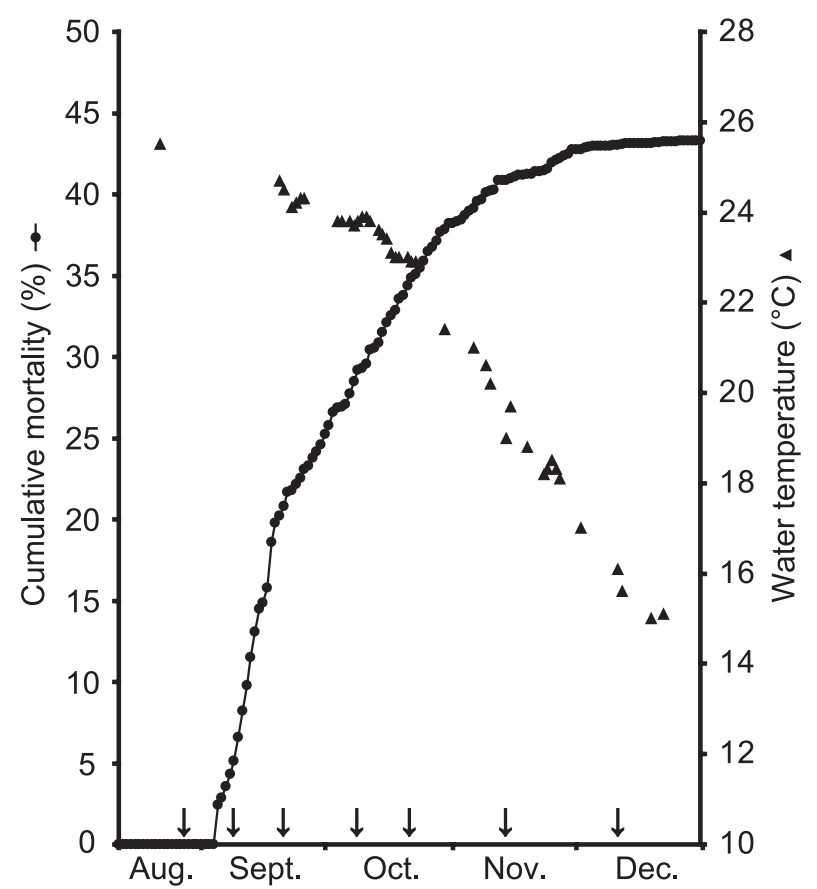

Fig. 4. Cumulative mortality of cultured Japanese flounder and water temperature in a farm. Arrows, fish and the serum sampling days.

Cumulative mortality of the fish and water temperature in the farm are shown in Fig. 4. During the sampling period, bacterial diseases due to $E$. tarda and $S$. parauberis had occurred in the farm. The causative agent was isolated from the brain or kidney with Salmonella-Shigella agar (Nissui) or Trypto-soya agar (Nissui) containing $2 \% \mathrm{NaCl}$ at $25^{\circ} \mathrm{C}$ and identified by the slide agglutination test with rabbit antiserum prepared against each bacterium. Results of the immunodot-blot test for each fish serum sample are shown in Table 1. The fish having the antibody against the fimbrial protein was observed on each sampling day. The number of the positive fish increased with the occurrence of death starting in the late August. This sug- gests that $E$. tarda expressing the fimbria infected Japanese flounder in the farm. In September, October and November, the fish without E. tarda was found in some fish showing the positive reaction. Although these fish have experienced the infection of $E$. tarda, the infected $E$. tarda would be killed by the host defense mechanism. The fimbrial protein may be immunogen against edwardsiellosis. On the other hand, E. tarda carrier was observed in the fish showing the negative reaction in the antibody test on each sampling day except November 14. Matsuyama et al. reported that some immune-related genes, i.e. MHC class II and immunoglobulin, of Japanese flounder have been down regulated for a few days after infection of $E$. $\operatorname{tarda}^{20)}$. Such carrier showing the negative reaction might not have been producing the antibody against fimbria in early phase of the infection.

The findings of the present study suggested that $E$. tarda with the fimbria was important for epidemics of edwardsiellosis at flounder farms. Some novel genes of putative adhesins have recently been identified in $E$. tarda by full-genome sequencing ${ }^{21)}$. The fimbria may serve as one of the adhesins for the infection to Japanese flounder. To understand the occurrence of disease and the infection process of E. tarda, further studies are needed regarding the detailed expression and function of fimbria.

\section{Acknowledgements}

We thank Professor K. Kanai (Nagasaki University) for kindly providing E. tarda NUF806 strain. This research was supported by a grant of research and development projects for application in promoting new policy of Agriculture Forestry and Fisheries.

\section{References}

1) Sakazaki, R. (2001): In "Bergey's Manual of Systematic

Table 1. Antibody reaction of Japanese flounder in a farm against $E$. tarda fimbrial recombinant protein

\begin{tabular}{clllllll}
\hline \multirow{2}{*}{ Fish No. } & \multicolumn{7}{c}{ Antibody reaction of (Bacteria isolation from) the farmed fish on } \\
\cline { 2 - 7 } & Aug. 28 & Sept. 9 & Sept. 22 & Oct. 9 & Oct. 22 & Nov. 14 & Dec. 11 \\
\hline 1 & $+{ }^{*}\left(\mathrm{Et} \mathrm{t}^{\dagger}\right)$ & + & $+(\mathrm{Et}, \mathrm{Sp})$ & $+(\mathrm{Et})$ & $+(\mathrm{Et})$ & $+(\mathrm{Et})$ & $+(\mathrm{Et})$ \\
2 & $+(\mathrm{Et})$ & + & $+(\mathrm{Sp})$ & + & $+(\mathrm{Et})$ & $+(\mathrm{Et})$ & $+(\mathrm{Et})$ \\
3 & $-(\mathrm{Et})$ & + & + & + & $+(\mathrm{Et})$ & $+(\mathrm{Sp})$ & + \\
4 & $-(\mathrm{Et})$ & $-(\mathrm{Et}, \mathrm{Sp})$ & + & $-(\mathrm{Et})$ & $+(\mathrm{Sp})$ & $+(\mathrm{Sp})$ & + \\
5 & $-(\mathrm{Et})$ & $-(\mathrm{Sp})$ & $-(\mathrm{Et})$ & $-(\mathrm{Et})$ & $+(\mathrm{Sp})$ & - & + \\
6 & $-(\mathrm{Et})$ & $-(\mathrm{Sp})$ & $-(\mathrm{Et})$ & $-(\mathrm{Et})$ & + & - & + \\
7 & $-(\mathrm{Sp})$ & $-(\mathrm{Sp})$ & $-(\mathrm{Et})$ & $-(\mathrm{Et})$ & + & - & $-(\mathrm{Et})$ \\
8 & $-(\mathrm{Sp})$ & - & $-(\mathrm{Sp})$ & $-(\mathrm{Et})$ & $-(\mathrm{Et})$ & - & $-(\mathrm{Et})$ \\
9 & - & - & $-(\mathrm{Sp})$ & - & - & - & $-(\mathrm{Et})$ \\
10 & - & - & $-(\mathrm{Sp})$ & - & - & - & - \\
\hline
\end{tabular}

$*+=$ antibody-positive reaction; - = negative reaction.

${ }^{\dagger} \mathrm{Et}=$ Edwardsiella tarda; $\mathrm{Sp}=$ Streptococcus parauberis. 
Bacteriology, 2nd Ed." (ed. by D. J. Brenner, N. R. Krieg, J. T. Staley and G. Garrity) Williams and Wilkins, Baltimore, pp. 657-661. 2) Alcaide, E., S. Herraiz and C. Esteve (2006): Dis. Aquat. Org., 73, 77-81. 3) Nakatsugawa, T. (1983): Fish Pathol., 18, 99-101. 4) Sae-Oui, D., K. Muroga and T. Nakai (1984): Fish Pathol., 19, 197-199. 5) Kanai, K., S. Tawaki and Y. Uchida (1988): Fish Pathol., 23, 41-47 6) Hirono, I., N. Tange and T. Aoki (1997): Mol. Microbiol., 24, 851-856. 7) Tan, Y. P., J. Zheng, S. L. Tung, I. Rosenshine and K. Y. Leung (2005): Microbiology, 151, 2301-2313. 8) Zheng, J. and K. Y. Leung (2007): Mol. Microbiol., 66, 1192-1206. 9) Yasunobu, H., Y. Arikawa, K. Furutsuka-Uozumi, M. Dombo, T. lida, M. M. Mahmoud, J. Okuda and T. Nakai (2006): Fish Pathol., 41, 29-34. 10) Mahmoud, M. M., J. Okuda and T. Nakai (2006): Fish Pathol., 41, 165-170. 11) Sakai, T., K. Kanai, K. Osatomi and K. Yoshikoshi (2003): FEMS Microbiol. Lett., 226, 127-133. 12) Sakai, T., T. lida, K. Osatomi and K. Kanai (2007): Fish Pathol., 42, 115-117. 13) Laemmli, U. K. (1970):
Nature, 227, 680-685. 14) Kim, W. S., T. Nishizawa and M. Yoshimizu (2007): Dis. Aquat. Org., 78, 55-59. 15) Sakai, T., T. Matsuyama, T. Nihsioka, C. Nakayasu, T. Kamaishi, K. Yamaguchi and T. lida (2009): J. Vet. Diagn. Invest., 21, 504-509. 16) Isshiki, T., T. Nishizawa, T. Kobayashi, T. Nagano and T. Miyazaki (2001): Dis. Aquat. Org., 47, 87-99. 17) Kanai, K., M. Yamada, F. Meng, I. Takahashi, T. Nagano, H. Kawakami, A. Yamashita, S. Matsuoka, Y. Fukuda, Y. Miyoshi, I. Takami, H. Nakano, T. Hirae, K. Shutou and T. Honma (2009): Fish Pahol., 44, 33-39. 18) Nakatsugawa, T. (1983): Fish Pathol., 17, 281-285. 19) Ito, T., K. Mori, M. Arimoto and K. Nakajima (2004): Fish Pathol., 39, 103-104. 20) Matsuyama, T., A. Fujiwara, C. Nakayasu, T. Kamaishi, N. Oseko, I. Hirono and T. Aoki (2007): Fish Shellfish Immunol., 22, 598-607. 21) Wang, Q., M. Yang, J. Xiao, H. Wu, X. Wang, Y. Lv, L. Xu, H. Zheng, S. Wang, G. Zhao, Q. Liu and Y. Zhang (2009): Plos One, 4, e7646. 